\title{
EFFect Of GRAPE SEed EXTRACt AND POWDeR ON OXIDANt StresS IN KIDNEY AND LIVER INJURY BY ALCL3
}

\author{
By \\ Samah A. Elsemelawy \\ Shimaa F.A.E. Ghozy \\ Home Economics Dept., \\ Faculty of Specific Education, \\ Home Economics Dept., \\ Faculty of Specific Education, \\ Tanta University, Egypt \\ Mansoura University, Egypt.
}

Research gournal Specific Fducation

Faculty of Specific Education

gMansoura University

ISSUE NO. 42, APRIL. 2016

مجلة بحوث التربية النوعية - جامعة المنصورة

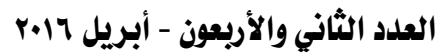


- Effect of Grape Seed Extract and Powder on Oxidant Stress in Kidney and Liver Injury 


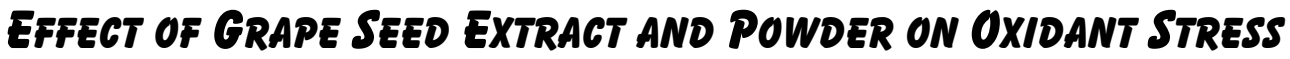 IN KIDNEY AND LIVER INJURY BY ALCL3
}

\author{
Samah A. Elsemelawy ${ }^{*} \quad$ Shimaa F.A.E. Ghozy ${ }^{* *}$
}

Abstract

The work aimed antioxidant properties of grape seed extract (GSE) against liver and kidney injury caused by ALCL3 in experimental rats. Twenty-five male Sprague-Dawley rats weighing $(155 \pm 5 \mathrm{~g})$ were used for 4 weeks. Rats classified into five groups (5 rats). The first group was used as a negative control and fed on basal diet only. The other four groups were administered ALCL3 at a single dose of $34 \mathrm{mg} / \mathrm{kg} / \mathrm{bwt}$ through the drink water to induce liver and kidney injury. One of these groups left as positive control (group 2). The third group was treated with $50 \mathrm{mg}$ grape seed proanthocyanidin extract $/ \mathrm{kg} / \mathrm{bwt}$ day. The fourth group was treated with 10 $\%$ grape seed proanthocyanidin powder $/ \mathrm{kg} /$ diet day. The fifth group was treated with $50 \mathrm{mg}$ grape seed proanthocyanidin extract $/ \mathrm{kg} / \mathrm{bwt}$ day and $10 \%$ grape seed proanthocyanidin powder $/ \mathrm{kg} /$ diet day.

The results showed that significant decrease in plasma and hepatic content analysis of grape seed extract and inhibited the levels of liver injury biomarkers (AST and ALT), also improved the kidney function enzymes. These results suggested that grape seed extract reduce organ injury through its ability to balance the oxidant-antioxidant status. This may be mediated by multiple pathways, including decreasing the oxidative stress and the great role of proanthocyanidin as a powerful antioxidant.

Key words: Grape Seed - Oxidant-Antioxidant Status - ALCL3 Ischemia

\footnotetext{
*Home Economics Dept., Faculty of Specific Education, Tanta University, Egypt

** Home Economics Dept., Faculty of Specific Education, Mansoura University, Egypt
} 


\section{Introduction}

Grapes (Vitis vinifera) are small round or oval berries that feature semi-translucent flesh encased by a smooth skin. Egyptians ate grapes at least 6,000 years ago, and several ancient Greek used the leaves and fruit of the grape to stop bleeding, inflammation, and pain, such as the kind brought on by hemorrhoids. Nowadays, an intense search for novel type of antioxidants is being carried out from numerous plant materials. Many plant extracts and plant products have been shown to possess a significant antioxidant activity. Today, grape seed extract is used to produce grape seed extract. The chemicals within the grapes, especially oligomeric proanthocyanidin complexes (OPCs) and proanthocyanidin (PA) have been touted as powerful antioxidants Bagchi, et al., (1997).

Proanthocyanidins are naturally occurring polyphenolic bioflavonoids in many fruits and vegetables. These compounds may also protect against oxidative damage of tissue by free radicals. One source of these antioxidants is grape seed proanthocyanidin extract (GSPE). Natural grape seed proanthocyanidins are a combination of biologically active polyphenolic flavonoids including oligomeric proanthocyanidins Ferreira and Li, (2000) and Carlson, et al., (2008).

These proanthocyanidins have been reported to have antiviral, antibacterial, anti-inflammatory and antiallergic activities and chemoprotective properties against oxygen free radicals and oxidative stress. The new studies found that taking grape seed extract substantially increased blood levels of antioxidants. Antioxidants are substances that destroy free radicals, which are harmful compounds in the body that damage DNA (genetic material) and even cause cell death. Scientists believe free radicals contribute to aging, as well as the development of a number of health problems, including heart disease and cancer Bagchi, et al., (1998) and Anastasiadi, et al., (2009).

Grape seed extract has also been demonstrated to protect cells from cytotoxicity induced by beta-amyloid pigmentation. In accordance with another study, feeding a strain of mice with Alzheimer's-like cognitive 
deficits grape seed extract (GSE) daily at $200 \mathrm{mg} / \mathrm{kg}$ for 5 months found cognitive improvement. In both studies grape seed extract (GSE) appears to reduce aggregation of beta-amyloid pigmentation in vitro Brooker, et al., (2006) and Wang, (2008).

Aluminium is one of the trace elements with a moderate toxic effect on living organism. Chronic exposition to this trace element can cause alterations in skeletal, nervous, hematopoietic and respiratory systems Afifi, (2002). Aluminium ions alter properties and structure of cellular membranes, inhibit many enzymes like alkaline phosphatase, acetylocholinesterase, and adenyl cyclase Platt, et al., (2001). In humans, chronic exposure to aluminium ions may result in mood changes, dysmnesia, convulsions, muscular weakness, pathological fractures of bones. Aluminium accumulates mainly in bones, spleen, liver and lungs causing serious injury to its cells Ward, et al., (2001).

It was our interest to look into the possible role of grape seed powder and extract (GSP\& GSE) as an effective antioxidant in liver and kidney. Therefore the objectives of the present study were framed to study grape seed powder and extract (GSP\& GSE) as an antioxidant in up-regulating the antioxidant defense mechanism against Anhydrous aluminum chloride $\left(\mathrm{AlCl}_{3}\right)$ induced liver and kidney injury.

\section{Materials and Methods}

\section{Materials}

Grapes: Grapes red and green were purchased from local market and dried in Cairo.

Anhydrous aluminum chloride ${ }^{\Theta}\left(\mathbf{A l C l}_{3}\right)$ : Anhydrous aluminum chloride was obtained from Sigma Chemical Co. (St Louis, Mo, USA).

Diet experimental rats: Casein (> 85\% protein) was obtained from Misr Scientific Company, Giza, Egypt. Cellulose and DL- methionine were purchased from Morgan Company, Cairo, Egypt. Minerals and vitamins constituent, sucrose, glucose and absolute ethanol were obtained from ElGomhoriya Pharm. and Chem. Ind. Co. Cairo, Egypt. Corn oil was obtained 
from the local market. Corn starch was obtained from Starch and Glucose Company, Helwan, Egypt.

Animals: Twenty-five male albino rats, Sprague Dawley strain, weighing $(155 \pm 5 \mathrm{~g})$ were purchased from the animal house of Agriculture Research Center, Giza, Egypt. The animals were housed in plastic cages, maintained on a natural light-dark cycle at room temperature of $26 \pm 2^{\circ} \mathrm{C}$ and fed standard diet according to Reeves, et al., (1993) and water ad libitum. The standard diet comprised of casein $(200 \mathrm{~g} / \mathrm{kg})$, corn starch $(497 \mathrm{~g} / \mathrm{kg})$, sucrose $(100 \mathrm{~g} / \mathrm{kg})$, cellulose $(30 \mathrm{~g} / \mathrm{kg})$, corn oil $(50 \mathrm{~g} / \mathrm{kg})$, mineral mixture $(100 \mathrm{~g} / \mathrm{kg})$, vitamins mixture $(20 \mathrm{~g} / \mathrm{kg})$ and DL-methionine $(3 \mathrm{~g} / \mathrm{kg})$.

Rats were kept for one week as acclimatization period before the start of the experiment period. All rats were handled in accordance with the standard guide for the care and use of laboratory animals.

\section{Methods:}

\section{Preparation of plant formulations:}

Fresh grape seed proanthocyanidin extract, were washed with water and dried by the hybrid solar convective drying system, belonging to the Solar Energy Dept., National Research Center, Dokki, Egypt, at $30-40{ }^{\circ} \mathrm{C}$.

The dried grape seed were ground to fine powder according to Russo, (2001) who reported that plant is best kept in a dry and dark location to reduce oxidation of its contents.

Methanol extact of grape seed was carried out according to Sobhy and Abdalla, (2009) 19; dried powder of grape seed was extracted using methanol at a ratio of 10:1, solvent: grape seeds. Extraction was carried out using a shaking incubator at room temperature for $24 \mathrm{~h}$ followed by filtration through whatman No.1 filter paper. The residue was re-extracted in the same manner and the two filtrates were combined.

\section{HPLC analysis of polyphenols and flavonoids:}

HPLC analysis of extracts was performed using an Agilent 1200 chromatograph equipped with a PDA model G1315B, a Bin pump model G1312A, an auto sampler model G1313A and a RR Zorbax Eclipse Plus 
C18 column $(1.8 \mu \mathrm{m}, 150 \mathrm{~mm} \times 4.6 \mathrm{~mm})$. The mobile phase A was $0.2 \%$ formic acid in water and the mobile phase B was acetonitrile. Elution was performed at $0.95 \mathrm{~mL}$ min- 1 with the following gradient program of solvent B: 0-20 min, 5-16 \%; 20-28 min, 16-40\%; 28-32 min, 40-70 \%; 32-36 min, 70-99 \%; 36-45 min, $99 \%$ and 45-46, min. 99-5\%.30 The injection volume was $10 \mu \mathrm{L}$. Wavelengths of $280 \mathrm{~nm}$ (for flavan-3-ols and benzoic acid derivatives) and $360 \mathrm{~nm}$ (for flavonols and cinnamic acid derivatives) were selected for detection according to Merfort, et al., (1997).

\section{Experimental design:}

The experiment was performed in Animal House in the Food Technology Research Institute, Agriculture Research Center, Giza. After the acclimatization period, rats were divided randomly groups:

Group (1): negative control ( $\mathrm{n}=5$ rats) fed on the basal diet only.

Group (2): Fed on the basal diet received were given daily $\mathrm{AlCl} 3$ via their drinking water $(34 \mathrm{mg} / \mathrm{kg} / \mathrm{bwt} 1 / 25 \mathrm{LD} 50)$ for 28 days according to Sigel and Sigel (1988).

Group (3): Fed on the basal diet and treated with (50 mg grape seed proanthocyanidin extract $/ \mathrm{kg} /$ day.

Group (4): Fed on the basal diet and treated with (10\% grape seed proanthocyanidin powder $/ \mathrm{kg} /$ diet day.

Group (5): Fed on the basal diet and treated with $50 \mathrm{mg}$ grape seed proanthocyanidin extract $/ \mathrm{kg} / \mathrm{bwt}$ day and $(10 \%$ grape seed proanthocyanidin powder $/ \mathrm{kg} /$ diet day.

Body weight (BW) was recorded weekly during the experimental period and feed intake was measured daily during the experimental periods.

\section{Blood sampling:}

At the end of the experiment period (4 weeks), rats were sacrificed after overnight fasting under ether anesthesia. Blood samples were taken from hepatic portal vein, small part was taken into heparinised tube and the remainder were left to clot by standing at room temperature for 15 minutes, and then centrifuged at $3000 \mathrm{rpm}$ for 20 minutes. Serum was carefully 
= Effect of Grape Seed Extract and Powder on Oxidant Stress in Kidney and Liver Injury

separated and transferred into clean quite fit plastic tubes and kept frozen at $-20^{\circ} \mathrm{C}$ until the time of analysis.

\section{Biological evaluation:}

At the end of the experiment, biological evaluation of the tested diets was carried out by determining total feed intake (FI) and body weight gain\% (BWG\%) according to Chapman, et al., (1959).

\section{Biochemical analysis:}

Determination of serum lipids patterns :

Enzymatic colorimetric determination of triglycerides was carried out according to Fossati and Prencipe, (1982). Total cholesterol was determined by colorimetric method according to Allian, et al., (1974). Determination of HDL (high density lipoprotein) was carried out according to the method of Fnedewaid, (1972). The determination of VLDL (very low density lipoproteins) and LDL (low density lipoproteins) were carried out according to the method of Lee and Nieman, (1996) by calculation as follows:

* VLDL $(\mathrm{mg} / \mathrm{dl})=$ Triglycerides $/ 5$

* LDL $(\mathrm{mg} / \mathrm{dl})=$ Total cholesterol -HDL-VLDL

Determination of kidney functions:

Serum creatinine, uric acid and urea were determined according to the methods described by Bohmer, (1971); Fossati, et al., (1980) and Patton and Crouch, (1977), respectively.

\section{Determination of liver enzymes:}

Serum alanine and aspartate aminotransferases (ALT \& AST) were estimated according to Reitman and Frankel, (1957).

\section{Determination of serum antioxidant parameters}

Superoxide dismutase (SOD) activity, total antioxidants capacity (TAC), and malondialdehyde (MDA) were determined according to Nishikimi, et al., (1972); Cao, et al., (1993) and Ohkawa, et al., (1979), respectively. 
$\overline{\underline{ }}$

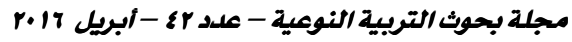

\section{Statistical analysis:}

The obtained data were statistically analyzed using computerized SPSS (Statistic Program Sigmastat, Statistical Soft-Ware, SAS Institute, Cary, NC). Effects of different treatments were analyzed by one way ANOVA (Analysis of variance) test using Duncan's multiple range test and $\mathrm{p}<0.05$ was used to indicate significance between different groups Snedecor and Cochran, (1967).

\section{Results and Discussion}

\section{1-The total concentration of phenolic compounds in grape seed extracts}

Data recorded in Table (1) represents the concentration of phenolic compounds in grape seed extracts $(\mathrm{mg} / 100 \mathrm{~g})$, the highest phenolic compound concentration in grape seed extracts was proanthocyanidin dimer, quercetin, ellagic acid, protocatechuic acid, proanthocyanidin trimer, quercetin-3-oglucuronide respectively $(578.14 \mathrm{mg}, 448.10 \mathrm{mg}, 433.45 \mathrm{mg}$, $342.05 \mathrm{mg}, 316.94 \mathrm{mg}, 304.05 \mathrm{mg})$.

\section{2-Effect of grape seed treatment on nutritional parameters in rats injury by ALCL3}

The statistical data in Table (2) indicated that, group (2) showed a significant decrease in body weight gain and feed intake compared to group (1) while the others groups $(3,4,5)$ showed significant increase in these parameters compared with group (2) while there was a decreasing in comparing to group (1). Similar results have been reported by Vogels, et al., (2004), they reported that Grape Seed Extract could reduce food intake in rats, and this was conducted in a human study which showed a reduction of energy intake by approximately $4 \%$ when no dietary controls are put in place, which is about 84 calories in said study.

This reduction in food intake was seen without observable influence on mood or satiety, and occurred after 3 days of intake of 300mg GSE (90\% proanthocyanidins) Yilmazer-Musa, (2012) reported that the grape seed extract (GSE) appears to inhibit alpha-amylase and may prevent carbohydrate absorption, with its IC50 and IC90 values slightly but nonsignificantly higher (less potent) than arcabose. These values (IC50 and 
IC90 in $\mathrm{ug} / \mathrm{mL}$ ) were $6.9+/-0.8$ and $42.8+/-4.7$ for arcabose and $8.7+/-0.8$ and 28.1+/-2.0 for GSE; both arcabose and GSE were significantly more effective than Green Tea Catechins and isolated EGCG, with IC50 values 47 times higher than GSE.This relatively potent inhibition by GSE was less than that observed with procyanidin compounds derived from Pycogenol, with an IC50 of $5 \mathrm{ug} / \mathrm{mL}$. It has also exerted inhibitory actions against pancreatic lipase in vitro, with $0.01,0.1$, and $1 \mathrm{mg} / \mathrm{mL}$ reducing lipase activity by 3, 22, and $80 \%$ respectively Moreno, (2003).

\section{3-Effect of grape seed treatment on lipid profile in rats injury by} ALCL3

The effects of grape seed supplemented in the form of powder and extract on serum lipid profile in $\mathrm{AlCl} 3$ induced liver and kidney injury in rats are shown in Table (3). Liver and kidney injury induced by $\mathrm{AlCl}_{3}$ (group 2) caused significant rise in total lipids, triglycerides, total cholesterol and LDL-C while, there was significant decrease in HDL-C in comparing to group (1). This is due to accumulation of aluminum in liver, kidneys and brain after excessive doses Daniel, et al., (2007).

On the other hand, the other groups (3, 4 and 5) showed significant decrease in serum total lipids, triglycerides, total cholesterol and LDL-C while increase in HDL-C compared to group (2). The best result of lipid profile was at group (5). Our results were matched with Preuss, et al., (2000) who reported the combination of chromium polynicotinate and GSE significantly decreased LDL when compared to placebo. He also concluded that GSE can decrease total cholesterol and LDL levels significantly.

Grape seed proanthocyanidin extracts (GSPE) reduce foam cells, prevent aortic atherosclerosis from developing in a hamster atherosclerosis model Auger, et al., (2004), decrease oxidized LDL in hypercholesterolemic humans and improve endothelial function by modifying NO production Bagchi, et al., ( 2003).

Consequently, they protect against atherosclerosis and CVD. Besides their antioxidant activity and their effects on the vascular endothelium, the 
antiatherogenic properties of PA are also related to an improved serum lipid profile. Plasma TG and apolipoprotein B (apoB) levels are reduced by GSPE in normolipidemic rats Del Bas, et al., (2005).

Quesada, et al., (2009) found that natural proanthocyanidins improve dyslipidemia associated with high-fat diet (HFDs), mainly by repressing lipogenesis and VLDL assembly in the liver, and he support the idea that they are powerful agents for preventing and treating lipid altered metabolic states. Also, Gene expression analyses revealed that proanthocyanidins repressed both the expression of hepatic key regulators of lipogenesis and very low density lipoprotein (VLDL) assembling such as SREBP1, MTP and DGAT2, all of which were overexpressed by the HFD.

\section{4-Effect of grape seed treatment on kidney and liver function in rats injury by ALCL3}

In Table (4), results showed that kidney function tests and liver function tests were elevated by $\mathrm{ALCL}_{3}$ injection in group (2). Liver and kidney Injury caused by $\mathrm{ALCL}_{3}$ led to change their function tests, as there was significant increase in uric acid ,urea, creatinine, AST and ALT in comparing to group (1). While the treatment groups with grape seed extract and grape seed powder improved the results as those levels were found to be significantly lower in comparing to group (2).

The treatment with grape seed extract enhanced the liver and kidney function tests of ALCL3 treated rats and brought this parameter back to values very similar to that observed in group (1). Recently Wei, (2012) reported the nephroprotective role of grape seed extract on renal ischemic induced kidney injury in mice. These studies showed that High dose GSE $(2.5 \mathrm{~g} / \mathrm{kg})$ for a week in rats subject to ischemia/reperfusion of the kidneys (an oxidative insult) noted that GSE was able to significantly attenuate the increase in Urea, Creatinine, and Cystatin C seen with I/R injury by $35.9 \%$, $36 \%$, and $34.3 \%$ respectively; suggesting less damage to glomerular function. Moreover, Ulusoy, (2012) concluded that grape seed extract possess Protective effects which have been noted against Cyclosporin-A induced nephrotoxicity at $100 \mathrm{mg} / \mathrm{kg}$ bodyweight where GSE normalized the 
increase in BUN and creatinine as well as the increased apoptosis (cell death) seen with CsA. Thus, it may be due to free radical scavenger and antioxidant activities of grape seed extract constituents, especially proanthocyanidin, quercetin and ellagic acid.

Treatment with GSE reversed the increasing of ALT and AST levels, this results were matched with Özer, et al., (2008) who reported that protective effects of grape seed extract on reperfusion-induced injury can be attributed, at least in part, to its ability to inhibit neutrophil infiltration, to balance oxidant-antioxidant status, and to regulate the generation of inflammatory mediators.

\section{5-Effect of grape seed treatment on serum antioxidant parameters in rats injury by ALCL3}

The effects of grape seed extract and grape seed powder on serum antioxidant parameters in ALCL3 injection induced liver and kidney injury are shown in Table (5). Liver and kidney injury induced by ALCL3 injection caused significant decrease in serum antioxidant enzyme activity; superoxide dismutase SOD and total antioxidants level compared to group (1). On the other hand, significant increasing was noticed in malondialdehyde MDA in group (2). Treatment with grape seed extract significantly attenuated the increased levels of MDA and elevated the serum antioxidant enzyme levels in comparing to group (2). The grape seed extract contain Proanthocyanidin which is an oligomeric flavonoids antioxidant protects against free radical molecules by altering molecular mechanisms in the blood vessels; reducing their susceptibility to damage through reduced activity of angiotensin that causing blood vessel constriction that would elevate blood pressure Kar, (2009).

This result was agreed with Nuttall, (1998) and Hsu, et al., (2009) who noted that 5 days of consumption of Grape Seed Extract increased total body anti-oxidant capacity 1 hour post-dose but did so without altering circulating levels of Vitamin $\mathrm{C}$ or Vitamin E. Furthermore, our results demonstrated that GSE treatment abolished these increases in malondialdehyde, probably in part by scavenging the very reactive hydroxyl 
and peroxyl radicals. El-Alfy, et al., (2005), demonstrated that grape seed proanthocyanidins, when administered to alloxaninduced diabetic rats, decreased the oxidant generation and lipid peroxidation by its antioxidant effect. Similarly, in the neonatal rats GSE suppresses lipid peroxidation and reduces hypoxic ischemic brain injury by reducing 8-isoprostaglandin F2 $\alpha$ and thiobarbituric acid reacting substances Feng, et al., (2005).

Oxidative stress-induced tissue damage can be prevented or ameliorated by favoring the balance towards a lower oxidative status. The results of the present study support the notion that decreasing of serum antioxidant enzymes, is one of the major factors that permit lipid peroxidation and subsequent tissue damage especially in liver and kidney. Furthermore, grape seed extract treatment reversed all the injury parameters and the levels of inflammatory mediators while protecting the liver tissue against reperfusion-induced oxidative injury Shao, et al., (2003).

In other study, Bagchi, et al., (2000) studied the dose-dependent free radical scavenging ability of a novel IH636 grape seed proanthocyanidin extract (GSPE) both in vitro and in vivo models, and compared the free radical scavenging ability of GSPE with vitamins $\mathrm{C}, \mathrm{E}$ and beta-carotene. $\mathrm{He}$ found that GSPE is highly bioavailable and provides significantly greater protection against free radicals and free radical-induced lipid peroxidation and DNA damage than vitamins $\mathrm{C}, \mathrm{E}$ and beta-carotene. GSPE was also shown to demonstrate cytotoxicity towards human breast, lung and gastric adenocarcinoma cells. GSPE provided significantly better protection as compared to vitamins $\mathrm{C}$ and $\mathrm{E}$, singly and in combination. GSPE also demonstrated excellent protection against acetaminophen overdose-induced liver and kidney damage by reducing oxidative stress.

\section{Conclusions}

In can be conclusions that the grape seed extract and grape seed powder demonstrated significant antioxidant activity in liver and kidney tissue and also decrease the levels of kidney and liver function. From the results of these studies, grape seed extract appears to be better at scavenging free radicals and preventing oxidative damage to kidney and liver tissue. 
= Effect of Grape Seed Extract and Powder on Oxidant Stress in Kidney and Liver Injury

Such a remarkable spectrum of biochemical and cellular functions holds promise for the prevention and treatment of a variety of human disorders caused by oxidative stress.

\section{References}

- Afifi, A. (2002): Renal osteodystrophy in developing countries. Artif.Organs. 26 (9), 767.

- Allian, C.; Poon, L.; Chan, C. and Richmond, W. (1974): Enzymatic determination of total serum cholesterol. Clin. Chem.; 20: 470.

- Anastasiadi, M.; Chorianopoulos, N. G.; Nychas, G. J. and Haroutounian, S. A. (2009): Antilisterial activities of polyphenol-rich extracts of grapes and vinification byproducts. J Agric Food Chem. 57(2):457-63.

- Bagchi, D.; Garg, A.; Krohn, R.; Bagchi, M.; Bagchi, D. J.; Balmoori, J. and Stohs S. J. (1998): Protection effects of grape seed proanthocyanidins and selected antioxidants against TPA-induced hepatic and brain lipid peroxidation and DNA fragmentation, and peritoneal macrophage activation in mice. Gen. Pharmacol. 30: 771-776.

- Bagchi, D.; Garg, A.; Krohn, R. L.; Bagchi, M.; Tran, M. X. and Stohs, S. J. (1997): Oxygen free radical scavenging abilities of vitamins $C$ and $E$ and a grape seed proanthocyanidin extract in vitro. Res. Commun. Mol. Pathol. Pharmacol. 95: 179-189.

- Bagchi, D.; Sen, C. K.; Ray, S. D.; Das, D. K.; Bagchi, M. and Preuss, H. G. (2003): Molecular mechanisms of cardioprotection by a novel grape seed proanthocyanidin extract. Mutat Res. 523-524: 87-97.

- Bagchi, D.; Bagchi, M.; Stohs, S. J.; Das, D. K.; Ray, S. D.; Kuszynski, C. A.; Joshi, S. S. and Pruess, H.G. (2000): Free radicals and grape seed proanthocyanidin extract: importance in human health and disease prevention. Toxicology. 2000 Aug 7; 148(2-3):187-97.

- Bohmer, H. (1971): Micro-determination of creatinine. Clin. Chem. Acta.; 32:81-85.

- Brooker, S.; Martin, S. and Pearson, A. (2006): Double-blind, placebocontrolled, randomised phase II trial of IH636 grape seed proanthocyanidin extract (GSPE) in patients with radiation-induced breast induration. Radiother Oncol. 79(1):45-51.

- Cao, G.; Alessio, H. and Cutler, R. (1993): Oxygen radical absorbance capacity assay for antioxidants. Free Radic Biol Med.; 14:303-311. 
- Carlson, S.; Peng, N.; Prasain, J .K. and Wyss, J. M. (2008): Effects of botanical dietary supplements on cardiovascular, cognitive, and metabolic function in males and females. Gend Med. 5 Suppl A:S76-90.

- Chapman, D.; Castilla, R. and Campbell, J. (1959): Evaluation of protein in food. I. A. Method for the determination of protein efficiency ratio. Can. J. Biochem. Physiol.; 37: 679-686.

- Daniel, K.; Robert, A.; Yokel, E.; David, B.; Joshua, C.; Jean, H.; Sam, K.; Joan L.; Amal, M. and Virginie, R. (2007): Human health risk assessment for aluminium, aluminium oxide, and aluminium hydroxide. J. Toxicol Environ Health B Crit Rev. 10(Suppl 1): 1-269.

- Del Bas, J. M.; Fernández-Larrea, J.; Blay, M.; Ardévol, A.; Salvadó, M. J. and Arola, L. (2005): Grape seed procyanidins improve atherosclerotic risk index and induce liver CYP7A1 and SHP expression in healthy rats. FASEB J. 19: 479-481.

- El-Alfy, A. T.; Ahmed, A. A. and Fatani, A. J. (2005): Protective effect of red grape seeds proanthocyanidins against induction of diabetes by alloxan in rats. Pharmacol Res 52: 264-270.

- Feng, Y.; Liu, Y. M.; Fratkins, J. D. and Leblanc, M. H. (2005): Grape seed extract suppresses lipid peroxidation and reduces hypoxic ischemic brain injury in neonatal rats. Brain Res Bull 66: 120-127.

- Ferreira, D. and Li, X. C. (2000): Oligomeric proanthocyanidins: naturally occurring-O-heterocycles. Nat. Prod. Res. 17: 193-212.

- Fnedewaid, W. T. (1972): Determination of HDL. Clin. Chem.; 8:499.

- Fossati, P. and Prencipe, L. (1982): Determination of triglycerides, Bicon Diagnostics, made in Germany. Clinical Chemistry; 28: 2077-2078.

- Fossati, P.; Prencipe, L. and Berti, G. (1980): Use of 3.5-dichloro-zhydroxybenzenesulfonic acid / 4 aminophenazone chromogenic systems in direct enzymic assay of uric acid in serum and urine. Clin. Chem.; 26:227- 231.

- Quesada, J.; Mdel, L.; Bas, D.; Pajuelo1, S.; Díaz1, J.; Fernandez-Larrea, M.; Pinent, L.; Arola, M.; Salvadó, J. and Bladé, C. (2009): Grape seed proanthocyanidins correct dyslipidemia associated with a high-fat diet in rats and repress genes controlling lipogenesis and VLDL assembling in liver. International Journal of Obesity. 33, 1007-1012. 
= Effect of Grape Seed Extract and Powder on Oxidant Stress in Kidney and Liver Injury

- Hsu, C. P.; Lin, Y. H.; Chou, C. C.; Zhou, S. P.; Hsu, Y. C.; Liu, C. L.; Ku, F. M. and Chung, Y. C. (2009): Mechanisms of grape seed procyanidininduced apoptosis in colorectal carcinoma cells. Anticancer Res. 29(1):283-9.

- Kar, P. (2009): Effects of grape seed extract in Type 2 diabetic subjects at high cardiovascular risk: a double blind randomized placebo controlled trial examining metabolic markers, vascular tone, inflammation, oxidative stress and insulin sensitivity. Diabet Med. 26(5):526-31

- Lee, R. and Nieman, D. (1996): Nutritional assessment. $2{ }^{\text {nd }}$ Ed., Mosby, Missoun, USA. (1): 672-688.

- Merfort, l.; Wary, V. and Willuhan, G. (1997): Flavonol triglycerides from seeds of Nigella Sativa. Phetochem. 46(2):359-363.

- Moreno, D. A. (2003): Inhibitory effects of grape seed extract on lipases. Nutrition. 19(10):876-9.

- Nishikimi, M.; Rao, N. and Yogi, K. (1972): Colorimetric determination of superoxide dismutase. Biochem. Biophys. Res. Common.; 46: 849-854.

- Nuttall, S. L. (1998): An evaluation of the antioxidant activity of a standardized grape seed extract, Leucoselect. J Clin Pharm Ther. 23(5):385-9.

- Ohkawa, H.; Ohishi, N. and Yagi, K. (1979): Assay for lipid peroxides in animal tissues by thiobarbituric acid reaction. Anal Bio.; 95: 351-358.

- Özer, T.; Yahya, O.; Ender, D.; Umit, T.; Feriha, E. and Goksel, T. (2008): Grape seed extract treatment reduces hepatic ischemia-reperfusion injury in rats. Pherytothrapy Research Phytother. Res. 22, 43-48.

- Patton, C. and Crouch, S. (1977): Determination of serum urea enzymatically. J. of Ana. Chem.; 49: 464 - 469.

- Platt, B.; Fiddler, G.; Riedel, G. and Henderson, Z. (2001): Aluminium toxicity in the rat brain:histochemical and immunocytochemical evidence. Brain.Res.Bull. 55 (2), 257.

- Preuss, H. G.; Wallerstedt, D.; Talpur, N.; Tutuncuoglu, S. O.; Echard, B.; Myers A.; Bui, M. and Bagchi, D. (2000): Effects of niacin-bound chromium and grape seed proanthocyanidin extract on the lipid profile of hypercholesterolemic subjects: a pilot study. Journal of Medicine. 31(5-6):227246.

- Reeves, P.; Nielson, F. and Fahmy, G. (1993): Reports of the American Institute of Nutrition, Adhoc Wiling Committee on reformulation of the AIN 93. Rodent Diet. J. Nutri.; 123: 1939-1951. 
- Reitman, S. and Frankel, S. (1957): Determination of serum alanine and aspartate aminotransferases (ALT \& AST). Clin .Path. Am. J.; 28: 57-63.

- Russo, E. (2001): Handbook of Psychotropic Herbs: A scientific analysis of herbal remedies for psychiatric conditions. The Haworth Herbal Press, Inc.

- Shao, Z. H., Becker, L. B. and Vanden Hoek, T. L. (2003): Grape seed proanthocyanidin extract attenuates oxidant injury in cardiomyocytes. Pharmacol Res 47: 463-469.

- Sigel, H. and Sigel, A. (1988): Metal ions in dialysis syndrome and aluminum intoxication. Nephron. 31:1-10.

- Snedecor, G. W. and Cochran, W. G. (1967): Statistical Methods; $7^{\text {th }}$ Ed., The Lowa State University Press., Ames, Lowa, U.S.A.

- Sobhy, M. M. and Abdalla, S. M. (2009): Total phenolic contents and antioxidant activity of corn tassel extracts. J. Food Chemistry 112, 595-598.

- Ulusoy, S. (2012): Anti-apoptotic and anti-oxidant effects of grape seed proanthocyanidin extract in preventing cyclosporine A-induced nephropathy. Nephrology (Carlton). 16:1-7.

- Vogels, N.; Nijs, I. M and Westerterp-Plantenga, M. S. (2004): The effect of grape-seed extract on $24 \mathrm{~h}$ energy intake in humans. Eur J Clin Nutr. 58(4):66773.

- Wang, J. (2008): Grape-derived polyphenolics prevent Abeta oligomerization and attenuate cognitive deterioration in a mouse model of Alzheimer's disease. $\mathbf{J}$ Neurosci. ,20, 1-5.

- Ward, R. J.; Zhang, Y. and Crichton, R. R. (2001): Aluminium toxicity and iron homeostasis.; J. Inorg.Biochem. 87 (1-2), 9.

- Wei, R. (2012): Grape seed proanthocyanidin extract reduces renal ischemia/reperfusion injuries in rats. Am J Med Sci. 17 (1), 7-14

- Yilmazer-Musa, M. (2012): Grape Seed and Tea Extracts and Catechin 3Gallates Are Potent Inhibitors of $\alpha$-Amylase and $\alpha$-Glucosidase Activity. J Agric Food Chem. 12;60 (36):8924-9. 
= Effect of Grape Seed Extract and Powder on Oxidant Stress in Kidney and Liver Injury

Table (1): The total concentration of phenolic compound of grape seed extracts

\begin{tabular}{||c|c|c||}
\hline phenolic compound & $\begin{array}{c}\text { RT min standard } \\
\text { retention ( RT) Min }\end{array}$ & $\begin{array}{c}\text { Mass } \\
\text { (mg/100g) }\end{array}$ \\
\hline \hline Gallic acid & 3.2 & 160.54 \\
\hline Protocatechuic acid & 4.0 & 342.05 \\
\hline Proanthocyanidin trimer & 4.3 & 316.94 \\
\hline Catechin & 5.8 & 270.09 \\
\hline Protocatechuic acid & 6.8 & 138.03 \\
\hline Caffeic acid & 8.2 & 187.23 \\
\hline Ellagic acid & 11.7 & 433.45 \\
\hline Proanthocyanidin dimer & 12.7 & 578.14 \\
\hline Isorhamnetin-3-Oglucoside & 15.5 & 304.83 \\
\hline Quercetin & 16.5 & 448.10 \\
\hline Quercetin-3-Oglucuronide & 17.6 & 304.05 \\
\hline
\end{tabular}

Table (2): Feed intake, body weight gain of different experimental rats groups

\begin{tabular}{|c|c|c||}
\hline Parameters & $\begin{array}{c}\text { Feed intake } \\
\text { g/day }\end{array}$ & $\begin{array}{c}\text { Body weight gain } \\
\text { \%roups }\end{array}$ \\
\hline \hline $\begin{array}{c}\text { Group 1 } \\
\text { Normal control }\end{array}$ & $19.33 \pm 2.31 \mathrm{a}$ & $96.10 \pm 9.80 \mathrm{a}$ \\
\hline $\begin{array}{c}\text { Group 2 } \\
\text { positive group }\end{array}$ & $13.75 \pm 2.75 \mathrm{c}$ & $51.15 \pm 7.62 \mathrm{c}$ \\
\hline $\begin{array}{c}\text { Group 3 } \\
\text { GSEX(50 mg/kg/bwt) }\end{array}$ & $15.99 \pm 2.19 \mathrm{~b}$ & $71.37 \pm 10.8 \mathrm{~b}$ \\
\hline $\begin{array}{c}\text { Group 4 } \\
\text { GSEP (10 mg/ kg/diet) }\end{array}$ & $16.12 \pm 2.43 \mathrm{~b}$ & $71.90 \pm 8.48 \mathrm{~b}$ \\
\hline $\begin{array}{c}\text { Group 5 } \\
\text { GSEX \& GSEP }\end{array}$ & $17.72 \pm 2.37 \mathrm{~b}$ & $72.12 \pm 9.19 \mathrm{~b}$ \\
\hline \hline
\end{tabular}

Values are expressed as mean \pm SD. Significance at $p<0.05$.

Values which don't share the same letter in each column are significantly different. 
Table (3): Lipid profile of different experimental rats groups

\begin{tabular}{|c|c|c|c|c|c|}
\hline Groups & $\begin{array}{c}\mathrm{TC} \\
\mathrm{mg} / \mathrm{dl}\end{array}$ & $\begin{array}{c}\text { TG } \\
\mathrm{mg} / \mathrm{dl}\end{array}$ & $\begin{array}{c}\text { VLDL-c } \\
\mathrm{mg} / \mathrm{dl}\end{array}$ & $\begin{array}{l}\text { LDL-c } \\
\mathrm{mg} / \mathrm{dl}\end{array}$ & $\begin{array}{c}\text { HDL-c } \\
\mathrm{mg} / \mathrm{dl} \\
\end{array}$ \\
\hline Group 1 & $130.67 \pm$ & $152.00 \pm$ & $30.4 \pm$ & $57.61 \pm$ & $42.6 \pm$ \\
\hline Normal control & $3.79 \mathrm{~b}$ & $10.07 \mathrm{c}$ & $4.01 \mathrm{c}$ & $5.12 \mathrm{c}$ & $8.46 \mathrm{a}$ \\
\hline Group 2 & $207.33 \pm$ & $241.33 \pm$ & $48.27 \pm$ & $132.07 \pm$ & $26.63 \pm$ \\
\hline positive group & $19.94 \mathrm{a}$ & $16.65 \mathrm{a}$ & $3.33 \mathrm{a}$ & $11.02 \mathrm{a}$ & $8.89 \mathrm{~b}$ \\
\hline Group 3 & $136.33 \pm$ & $187.02 \pm$ & $37.4 \pm$ & $58.26 \pm$ & $40.67 \pm$ \\
\hline GSEX(50 mg/kg/bwt) & $5.51 \mathrm{~b}$ & $11.79 \mathrm{bc}$ & $7.28 \mathrm{bc}$ & $7.57 \mathrm{c}$ & $3.06 \mathrm{a}$ \\
\hline Group 4 & $175.67 \pm$ & $211.67 \pm$ & $42.33 \pm$ & $100.61 \pm$ & $32.67 \pm$ \\
\hline GSEP $(10 \mathrm{mg} / \mathrm{kg} /$ diet $)$ & $17.54 \mathrm{ab}$ & $12.85 \mathrm{ab}$ & $4.57 \mathrm{ab}$ & $10.47 \mathrm{~b}$ & $5.51 \mathrm{ab}$ \\
\hline Group 5 & $138.67 \pm$ & $164.33 \pm$ & $32.87 \pm$ & $68.47 \pm$ & $37.33 \pm$ \\
\hline GSEX \& GSEP & $14.01 \mathrm{~b}$ & $11.01 \mathrm{bc}$ & $5.60 \mathrm{bc}$ & $9.71 \mathrm{c}$ & $6.03 \mathrm{a}$ \\
\hline
\end{tabular}

Values are expressed as mean \pm SD.

Significance at $\mathrm{p}<0.05$.

Values which don't share the same letter in each column are significantly different.

TC: Total cholesterol TG: Triglyceride LDL: Low density lipoprotein cholesterol

HDL: High density lipoprotein cholesterol VLDLc: Very low density lipoprotein cholesterol

Table (4): Kidney and liver functions of different experimental rats groups

\begin{tabular}{|c|c|c|c|c|c|}
\hline Groups & $\begin{array}{c}\text { Uric acid } \\
\mathrm{mg} / \mathrm{dl}\end{array}$ & $\begin{array}{l}\text { Urea } \\
\mathrm{mg} / \mathrm{dl}\end{array}$ & $\begin{array}{c}\text { Creatinine } \\
\mathrm{mg} / \mathrm{dl}\end{array}$ & $\begin{array}{c}\text { AST } \\
(\mathbf{I u} / \mathbf{m l}) \\
\end{array}$ & $\begin{array}{l}\text { ALT } \\
(\mathbf{I u} / \mathbf{m l}) \\
\end{array}$ \\
\hline Group 1 & $2.73 \pm$ & $42.67 \pm$ & $1.02 \pm$ & $41.67 \pm$ & $37.67 \pm$ \\
\hline Normal control & $0.78 \mathrm{~b}$ & $3.06 \mathrm{c}$ & $0.07 \mathrm{~b}$ & $8.50 \mathrm{~b}$ & $3.21 \mathrm{c}$ \\
\hline Group 2 & $5.20 \pm$ & $70.03 \pm$ & $1.97 \pm$ & $78.67 \pm$ & $74.67 \pm$ \\
\hline positive group & $0.52 \mathrm{a}$ & $2.65 \mathrm{a}$ & $0.31 \mathrm{a}$ & $9.07 \mathrm{a}$ & $6.81 \mathrm{a}$ \\
\hline Group 3 & $2.79 \pm$ & $56.11 \pm$ & $1.30 \pm$ & $46.33 \pm$ & $48.33 \pm$ \\
\hline $\operatorname{GSEX}(50 \mathrm{mg} / \mathrm{kg} / \mathrm{bwt})$ & $0.72 \mathrm{~b}$ & $3.21 \mathrm{bc}$ & $0.17 \mathrm{~b}$ & $6.03 \mathrm{~b}$ & $8.92 \mathrm{bc}$ \\
\hline Group 4 & $3.82 \pm$ & $61.67 \pm$ & $1.41 \pm$ & $45.02 \pm$ & $46.12 \pm$ \\
\hline GSEP $(10 \mathrm{mg} / \mathrm{kg} /$ diet $)$ & $0.93 \mathrm{ab}$ & $6.35 \mathrm{ab}$ & $0.22 \mathrm{~b}$ & $3.46 \mathrm{~b}$ & $9.64 \mathrm{bc}$ \\
\hline Group 5 & $2.80 \pm$ & $56.01 \pm$ & $1.17 \pm$ & $43.01 \pm$ & $38.67 \pm$ \\
\hline GSEX \& GSEP & $0.46 \mathrm{~b}$ & $8.46 \mathrm{bc}$ & $0.06 \mathrm{~b}$ & $7.32 \mathrm{~b}$ & $8.08 \mathrm{bc}$ \\
\hline
\end{tabular}

Values are expressed as mean \pm SD.

Significance at $\mathrm{p}<0.05$.

Values which don't share the same letter in each column are significantly different.

ALT:alanine aminotransferase enzymes AST:aspartate aminotransferase enzymes 
= Effect of Grape Seed Extract and Powder on Oxidant Stress in Kidney and Liver Injury

Table (5): Serum antioxidant parameters of different experimental rats groups

\begin{tabular}{|c|c|c|c|}
\hline Groups & $\begin{array}{c}\text { Superoxide } \\
\text { dismutase (SOD) } \\
\mathrm{U} / \mathrm{mL} \\
\end{array}$ & $\begin{array}{c}\text { Total } \\
\text { antioxidants } \\
\text { mmol/L } \\
\end{array}$ & $\begin{array}{c}\text { Malondialdehyde } \\
\mathrm{mmol} / \mathrm{L}\end{array}$ \\
\hline Group 1 & $198.23 \pm$ & $3.1 \pm$ & $4.47 \pm$ \\
\hline Normal control & $12.74 \mathrm{a}$ & $0.75 \mathrm{a}$ & $0.76 \mathrm{c}$ \\
\hline Group 2 & $114.33 \pm$ & $1.17 \pm$ & $11.05 \pm$ \\
\hline positive group & $12.01 \mathrm{c}$ & $0.55 \mathrm{~b}$ & $1.16 \mathrm{a}$ \\
\hline Group 3 & $153.33 \pm$ & $1.99 \pm$ & $5.11 \pm$ \\
\hline GSEX $(50 \mathrm{mg} / \mathrm{kg} / \mathrm{bwt})$ & $14.81 \mathrm{~b}$ & $0.80 \mathrm{ab}$ & $0.62 \mathrm{c}$ \\
\hline Group 4 & $156.01 \pm$ & $2.01 \pm$ & $5.21 \pm$ \\
\hline GSEP $(10 \mathrm{mg} / \mathrm{kg} /$ diet $)$ & $12.10 \mathrm{~b}$ & $0.09 \mathrm{ab}$ & $0.32 \mathrm{c}$ \\
\hline Group 5 & $183.33 \pm$ & $2.73 \pm$ & $4.76 \pm$ \\
\hline GSEX \& GSEP & $14.15 \mathrm{a}$ & $0.68 \mathrm{a}$ & $0.43 \mathrm{c}$ \\
\hline
\end{tabular}

Values are expressed as mean \pm SD.

Significance at $\mathrm{p}<0.05$

Values which don't share the same letter in each column are significantly different. 


\title{
تأثير هسحوق ومستخلص بذور العنب على الاجهاد التأكسدي الناتج عن اصابة الكسى والكبد بواسطة ثلاثي كلوريد الالوهنيومه بوري
}

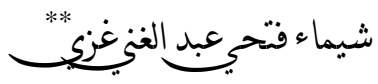

\author{
الملاخص العربي
}

الشقوق الحـرة تتسبب يِّ اصـابة الانسـان بالعديـد مـن المشاكل المرضية مثل نقص وصـول

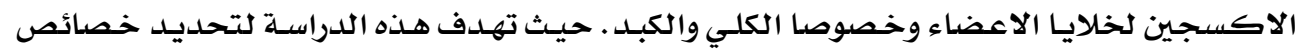

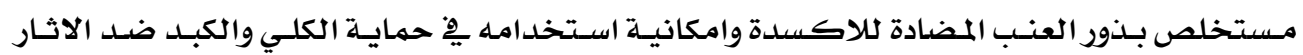

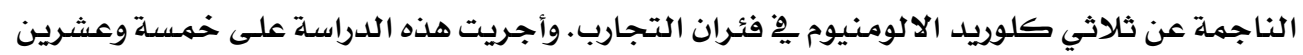

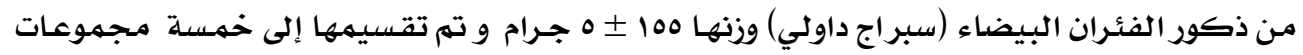

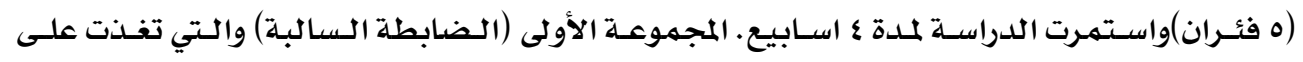

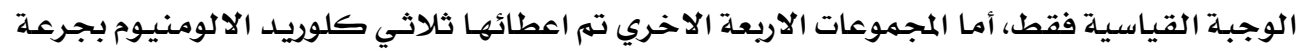

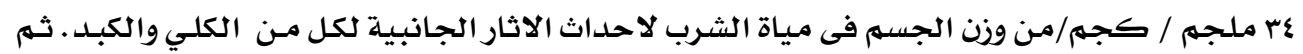

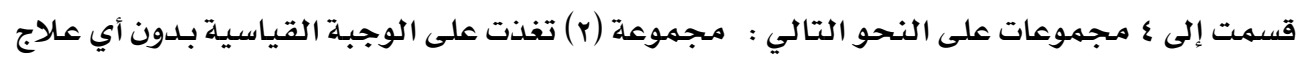

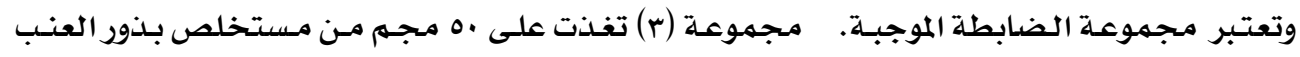

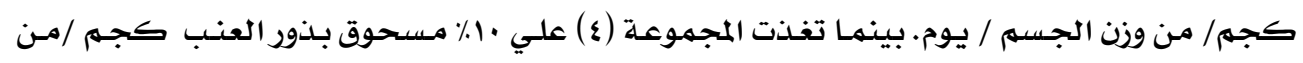

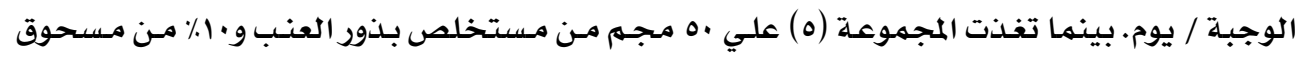

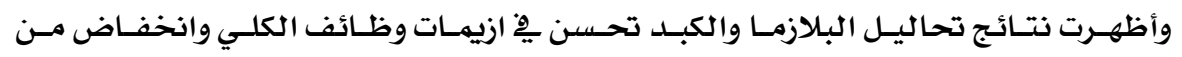

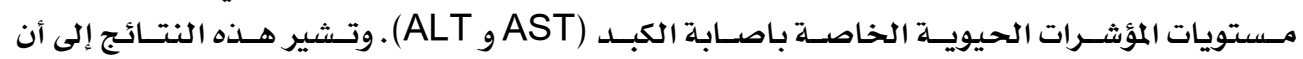

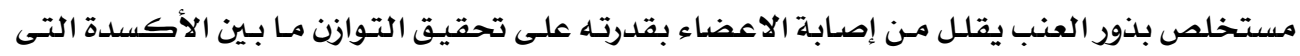

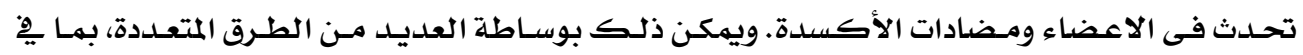

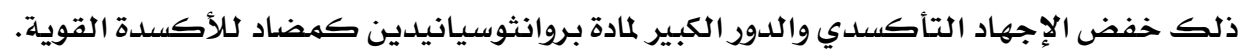

قسم الاقتصاد المنزلي - كلية التربية النوعية - جامعة طنطا - مصر. قسم الاقتصاد المنزلي - كلية التربية النوعية- جامعة المنصورة - مصر. 